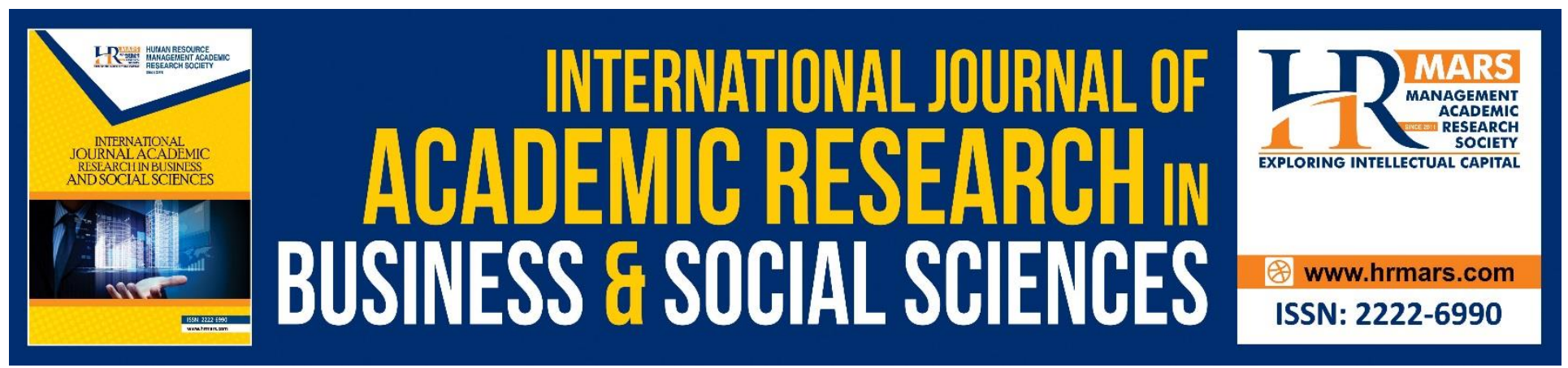

\title{
Malaysian Military Armoured Vehicle Procurement and its Impact on Employees' Societal Welfare (Quality of Life)
}

Nurhanis Amalina Roslan, Jegak Uli, Mohd Nor Yahaya \& Mahendra K Sekaran Nair

To Link this Article: http://dx.doi.org/10.6007/IJARBSS/v8-i6/4310

DOI: $\quad 10.6007 /$ IJARBSS/v8-i6/4310

Received: 21 May 2018, Revised: 23 June 2018, Accepted: 29 June 2018

Published Online: 08 July 2018

In-Text Citation: (Roslan, Uli, Yahaya, \& Nair, 2018)

To Cite this Article: Roslan, N. A., Uli, J., Yahaya, M. N., \& Nair, M. K. S. (2018). Malaysian Military Armoured Vehicle Procurement and its Impact on Employees' Societal Welfare (Quality of Life). International Journal of Academic Research in Business and Social Sciences, 8(6), 1160-1169.

Copyright: (C) 2018 The Author(s)

Published by Human Resource Management Academic Research Society (www.hrmars.com)

This article is published under the Creative Commons Attribution (CC BY 4.0) license. Anyone may reproduce, distribute, translate and create derivative works of this article (for both commercial and non-commercial purposes), subject to full attribution to the original publication and authors. The full terms of this license may be seen

at: http://creativecommons.org/licences/by/4.0/legalcode

Vol. 8, No. 6, June 2018, Pg. 1160 - 1169

Full Terms \& Conditions of access and use can be found at http://hrmars.com/index.php/pages/detail/publication-ethics 


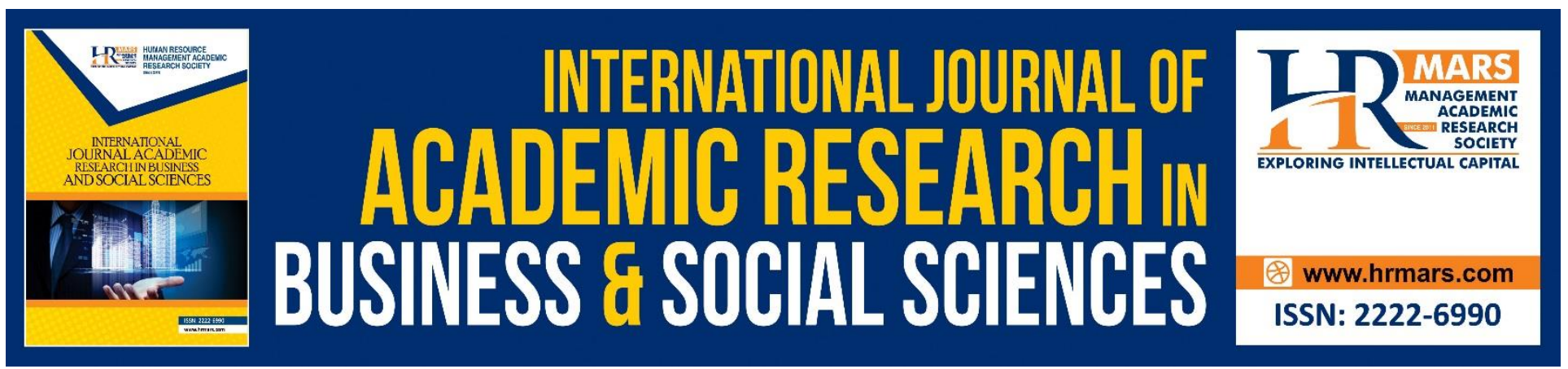

\title{
Malaysian Military Armoured Vehicle Procurement and its Impact on Employees' Societal Welfare (Quality of Life)
}

\author{
Nurhanis Amalina Roslan ${ }^{1}$, Jegak Uli', \\ Mohd Nor Yahaya ${ }^{1} \&$ Mahendra K Sekaran Nair ${ }^{1}$ \\ ${ }^{1}$ National Defence University of Malaysia, 57000 Kem Sungai Besi, Kuala Lumpur
}

\begin{abstract}
The main objective of this research is to investigate the Malaysian military armoured vehicle procurement and its impact on employees' societal welfare (quality of life). The specific research objectives are: (a) to determine the level of employees' quality of life, (b) to determine the relationship between selected demographic profiles (gender, education attainment, job category and vehicle types) and quality of life, (c) to determine main effect of gender, education attainment, job category and vehicle types on quality of life and (d) to determine the interaction effect of gender, education attainment, job category and vehicle types on quality of life. The research methods design for this study employs both expo-facto and correlational descriptive research. The data will be collecting at a single point in time and thus it is a cross-sectional study using an adopted and adapted Quality of Life questionnaire. The instrument was tested on 81 employees who were randomly selected from DRB-Hicom Defence Technologies Sdn. Bhd. (DEFTECH), Pekan Plant, Pahang and Defence Services Sdn. Bhd. (DSSB), Nilai, Negeri Sembilan. Analysis of the reliability of the instrument shows that the range of Cronbach's Alpha values obtained from .840 to .965 suggesting excellent reliability. This instrument with a reliable and valid constructs would be used in the next phase of our research that is to evaluate the extent of quality of life of the employees of this two private local defence industry. This study fills the gap by looking at the impact of armoured vehicle offset procurement on the societal welfare particularly on the quality of life.
\end{abstract}

Keywords: Military Armoured Vehicle Procurement, Malaysian Army, Societal Welfare, Quality Of Life

\section{Introduction}

The nation's ability on defense depends on the strength of their armed forces. According to Neuman (2010) the defense acquisition, technology and logistics are the three factors that may affect the strength of the armed forces. Otieno \& Noor (2014) stated that logistics plays a prominent role in designing, planning, acquiring and carrying out the movement of the forces including their combat equipment and supplies in the battlefield. Bradford (2006) asserted that other logistics aspects such 
as the procurement, maintenance, and movement of men, equipment, facilities and supplies are also important. The ability to maintain logistical support in the long terms requires a careful planning. For instance, Malaysian Armed Forces Headquarters is responsible in planning the logistic support such as service support, civil national support and international support (Mohamad Faisol \& Mohamad Hanapi, 2016) for MAF operations. In order to build a firm defence posture, the country need the support from defence industry and also defence science technology (National Defence Policy, 2004). A strong defence industry helps in reducing the nation's hinge on foreign manufacturers and suppliers, hence, building up national self-reliance. Therefore, the government has taken steps with offering cooperation with the local defence industry for smoothing the development and modernise of the armed forces equipment. Typically, Malaysia uses the National Defence Production Policy (NDPP) developed in 1982 for the best direction of defence industrial planning (Kogi Balakrishnan \& Matthews, 2009). One of the focus area in defence industry is land sector especially in armoured vehicles (AVs). Currently, DEFTECH Sdn Bhd and and DSSB Sdn Bhd are the two local private companies responsible for assembly, maintenance, repair and overhaul (MRO), manufacturing and supply of AVs and other logistics vehicles for Malaysian Army (Mohammed Ahmedullah, 2013). These companies are the subsidiary of DRB-HICOM, Malaysia's largest defence industry conglomerate (Amril Samsudin \& Shaik Abbas Ibrahim, 2015; Kogi Balakrishnan \& Matthews, 2009). AVs play a significant role in projecting combat power for the Malaysian Army through their inherent characteristics of fire power, mobility, protection and communication (Kwong, 2014; Kwong et al., 2016).

\section{An Overview of the History of Armoured Vehicles Procurement in the Malaysian Army}

Heuninckx (2015) asserted that military AVs build exceptionally with technical requirements was not found in the non-military environment such as survivability, night operations, robustness (Ministry of Defence, 2004), balancing armour, firepower, manoeuvrability (ADJ, 2010). The reliability of AV protection is a key feature in safety of transported armed forces (Skorupka et al., 2011). For example, whilst in ancient times, the horse wagon armoured only paired with hardwood or metal plates to ensure the safety of the soldiers in it. The strong endurance like body armours, protected vehicles and standoff weapons (Heuninckx, 2015) need consideration for greater mobility performance Midhun Eliyas \& V. Hima Kiran Vithal, 2014; Rozali et al., 2009) for better shooting, scoot capabilities and equipped with weapons such as the gun turret weapon platform on top of the vehicle (Aparow et al., 2015). As allude to earlier, the modern battlefield nowadays demands that wars be fought in all eight dimensions: space, cyber, air, land, sea, sub-surface, human minds (Yogesh Kapoor, 1990) and information technology (Mohammed Ahmedullah, 2009).

In Malaysian context, MAF requires the necessary military hardware and software in order to carry out its functions effectively in land, air and sea. Compare to air and sea, the land sector is meant to be the oldest, most matured and central (Antill, 2014) in Malaysia. Due to the initial threat that faced the nation, AVs are required in large numbers for myriad roles ranging from conventional war to counter insurgency operations, to counter terrorism and to peacekeeping operations. For instance, Malaysia's requirement for AV necessity developed whilst the Malayan Communist Party insurgency occurred in Tanah Melayu in 1948-1989 (Kogila Balakrishnan, 2008). The escalation of counter insurgency developed the necessity for procurement in many variants of AV to support the Malaysian Army in the recent past. 
INTERNATIONAL JOURNAL OF ACADEMIC RESEARCH IN BUSINESS AND SOCIAL SCIENCES

Vol. 8, No. 6, June 2018, E-ISSN: 2222-6990 @ 2018 HRMARS

Based on Kwong (2014) and Kwong et al. (2016) studies, the Malaysian Army have procured many variants of $\mathrm{AV}$ for its combat forces. The outset of Malaysian Army procurement begin when the usage of seconded Daimler and the Ferret Scout Cars from British in 1950s. The Malaysian Army had progressed into the procurement of Commando Armoured Fighting Vehicles (AFVs) and Panhard Armoured Personnel Carrier (APC) in the late of 1960s and 1970s. By the earliest of 1980s, the Sibmas Armoured Fire Support Vehicles (AFSVs) 6x6 from Belgium, the Condors 4x4 APC from Germany and the Scorpion Combat and Reconnaissance Tracked AV from the United Kingdom were procured to replace an AV in 1960s and 1970s. For the deployment in Bosnian War, Malaysian Infantry Fighting Vehicle (MIFV) was procured from South Korea in the 1990s. Later, the ACV-300 Adnan Armoured Infantry Fighting Vehicle (AIFV) is spoked to come into service in 2000 and Pendekar Main Battle Tank (PT-91M) from Poland to equip the Tank Regiment in 2009. The Sibmas AFSV $6 \times 6$ and the Condor $4 \times 4$ APC have served the Malaysian Army well since 1981. Thus, the Malaysian Army has in mind the replacement programme for both vehicles through AV-8 procurement plan (Irman Moad, 2010). Afterthought depth of plan, the Malaysian Army hitherto purchased 257 Gempita wheeled AV 8x8 (AV8 Gempita) worth RM7.55 billion (ADJ, March 2014) from FNSS Savunma Sistemleri A.S., Turkey for two Armoured Regiments and a Mechanised Battalion. Resulted from these, the government invests a myriad amount on defence procurement to modernise their armed forces as well as towards Malaysia's develop nation.

\section{Defense Offset Procurement}

As observed by Defence Industry Blueprint (2004), in order to be self-reliance on the defence capabilities, the Government of Malaysia had undertaken a numbers of procurement exercises through various countertrades, offset programmes, transfer of technology, incentive to the industries and research and development (R\&D). Earlier work by Kogila Balakrisnan (2007) indicates a vital role in nurturing Malaysia's defence industry through mechanisms such as defence procurement and offsets. In the military, the word 'procurement' is used rather than the straightforward 'purchase' (Green \& Irving, 1976) and 'acquisition' or 'commissioning' (McGuffog, 2011). According to Markowski \& Hall (1998), defence procurement is a contract deals for defence equipment prominent for being complex and risky business that usually involves the defence organisation and industry as two principal parties in procurement transactions. Besides, there are many factors that must considered when determining the defence procurement process such as taking a long time to develop (Dirksen, 1998), a number of specific stages, risks both now and in the future (Federal Highway Administration, 2012) and high cost (Heuninckx, 2008; Jonanthan Aitken MP, 1994; Ministry of Defence, 2004) such as rising manufacturing cost, R\&D cost, operating and maintenance cost, spare part cost (Neuman, 2010) to deliver the required capability. Contrary to that, Ministry of Defence, United Kingdom was inspired by the 'smart procurement' in 1997 able to reduce costs and diversifying its procurement (Guillou et al., 2009). For further understanding, Kogila Balakrishnan (2007) declared most of these purchases are made through a mechanism known as 'defence offsets procurement'.

These offset programmes categorised into direct and indirect offset (Ministry of Finance, 2011). Zailani (2014) supported offsets as a tool for enhancing and strengthens the defence industrial base, employment, skilled human resources, and technology development capability. Contrast to that, Kirchwehm (2014a, 2014b) showed offset is not one of the main guarantees to increase the level of employment in the development of the defence industry technology. Moreover, Kogila Balakrishnan (2008), Syariffudin Tippe (2013) and Ungaro (2013) asserted offset is very complex activities. 
Over the past several years, a number of researchers have examined procurement and offset programmes particularly concerned about transfer of technology (Kogila Balakrishnan, 2007; Kogila Balakrisnan, 2008; Kwong Fook Wen et al., 2016; Markowski \& Hall, 1998; Ministry of Finance Malaysia, 2011). As results from literature review, no empirical research has been carried out to assess the impact of this defence offset procurement on the societal welfare benefit to it in Malaysia. The societal welfare impact will be studied for only three AV namely: Adnan Armoured Infantry Fighting Vehicles (AIFV) 2000s, PT-91 Pendekar Main Battle Tanks (PT-91M) 2009s and Gempita Wheeled Armoured Vehicles $8 \times 8$ (2010s) because they are still in service. This study fills the gap by looking at the impact of AV offset procurement on the societal welfare particularly on the QOL.

\section{Societal Welfare}

The results of AVs offset procurement led by government; there are some societal welfare impacts that can be seen in the local automotive industry directly and indirectly. First, it provides many job opportunities to the surrounding communities, specifically local people in Pekan, Pahang and Nilai, Negeri Sembilan. For example, they can take opportunity to work in DEFTECH Sdn. Bhd. and DSSB Sdn. Bhd. They can generate their own income and become productive workers in the industry. In fact, the establishment of DRB-HICOM University (DRB-HICOM U) at Pekan on 2 April 2010 aims to produce professional workforce for the needs of the automotive sector in Malaysia is a prestigious effort. Second, the transformation of rural infrastructure may improve their well-being. For instance, by putting DEFTECH in Pekan has made its busier with the public and military vehicle industry activities and hoping to establish as DRB-HICOM Automotive City. Besides, there was another four company owned by DRB-HICOM group operating in this automobile such as Malaysian Trucks and Bus Sdn. Bhd. (MTB), Automotive Manufacturers (Malaysia) Sdn. Bhd. (AMM), Master Builders Sdn. Bhd. and Radiator Builders Sdn. Bhd (Utusan Online, 2000). Meanwhile, the location of DSSB located next to various factories at Nilai Industrial Estate also enhances the well-being of the locals and workers there in particular.

Based on these observations, there are many employment opportunities offered to local community as a result of the growth of these companies. Whereas from the perspective of employees involved in the industry, they are able to sharpen skills, utilise existing talents, increase productivity and learn all aspects involving the MRO and manufacture of AV. Only selected people are able to venture into a 'unique' field compare to public transport system in Malaysia. In fact, it can take on the challenge of the government in building and improving the capabilities of MAF in general. Subsequently, this societal welfare impacts may give positive figure to the development and modernisation of MAF, thus towards Malaysian innovative and industrial nation by 2020 (DESIB, 2013; Mohamad Faisol et al., 2016).

Societal welfare in this study is operationally measured by QOL instrument developed by Jegak Uli et al. (2008). For this research, the dependent variable is QOL where else the independent variable is parameters involving the domains of demographic profiles that impact to the employees' QOL. The four domains of demographic profiles were selected consist of gender, education attainment, job category and vehicle types will be measuring. The model for Malaysian military armoured vehicle procurement and its impact on societal welfare is conceptualized as an integrated model of a linear relationship between the dependent variable (QOL) and the independent variable (demographic profiles). The specific research objectives are: (a) to determine the level of employees' quality of life, (b) to determine the relationship between selected demographic profiles (gender, education attainment, job category and vehicle types) and quality of life, (c) to determine main effect of gender, 
education attainment, job category and vehicle types on quality of life and (d) to determine the interaction effect of gender, education attainment, job category and vehicle types on quality of life. Therefore, these research objectives will be analysing using descriptive statistics, independent t-test and two-way ANOVA from the SPSS Statistics. Thus, the proposed theoretical framework for this research is as shown in Figure 1 below.

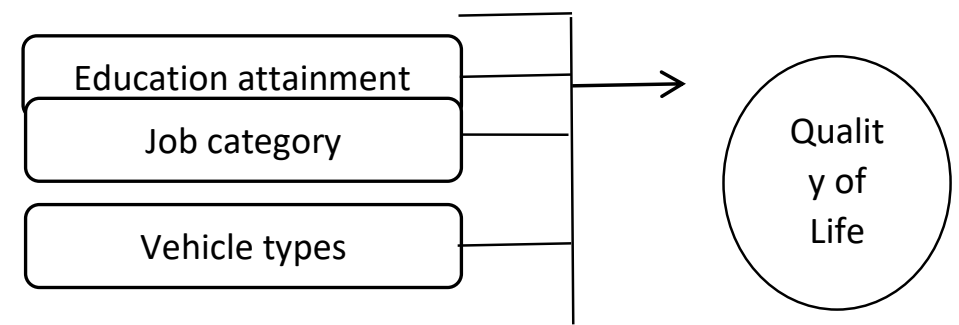

Figure 1. Proposed Theoretical Framework

There are two strong prongs for undertaking QOL as measurement in this study. First, QOL were selected for societal welfare measurement because it is one of the areas of concern to the researchers nowadays (Hambleton et al., 2008; Kaplan \& Ries, 2007; Ruževičius, 2014; Sylvester \& Tosin, 2016). Second, resulted from discussion with Technology Depository Agency (TDA) of Malaysia, they were recommended the QOL as benchmark for societal welfare as well as state in Zailani (2014). The QOL has a variety of purposes depending on how one sees its importance and affects their lives. According to Theofilou (2013), QOL defined as the life experience of an individual in fulfilling his will through social life, the environment, the physical and psychological value. Ruževičius (2014) stated QOL an economic concept, sociology and political science that embraces internal (emotional), social and physical well-being. In French, QOL is known as Qualité de vie and Qualität des Lebens in German. Furthermore, Massam (2002) view we have the right to create a distinctive lifestyle in this life as it fulfils goodness, happiness, family, community and so on. For instance, the main role of the government and the private sector to improve the quality of life of its employees through the provision of appropriate remunerations and benefits, interpersonal relationships, conducive of work environment, accurate exposure on organisational support and facilities, and organisational policies and management style, safety and security, can spend time with family and their self, taking into consideration their health and well-being as stated in the QOL instrument developed by Jegak Uli et al. (2008). Thus, the concept QOL is compatible with the proposed theoretical framework and the items in adopted and adapted QOL instrument in this study.

\section{The Quality of Life Instrument}

The studies done by Jegak Uli et al. (2008) describing the factors affecting QOL and performance in relation to selected work systems in Malaysian public sector. For this study context, a certain part of QOL questionnaire from his team was selected. A cross-sectional study have been carried out to tailor selected items for the use to assess the societal welfare of DEFTECH and DSSB employees' via armoured vehicle procurement Malaysia. Therefore, the nine dimensions and only 65 items of QOL in this questionnaire were selected. The nine dimensions are the remunerations and benefits ( 9 items), job characteristics (8 items), interpersonal relationships (7 items), work environment (6 items), organisational support and facilities ( 7 items), organisational policies and management styles ( 8 items), safety and security ( 5 items), individual and family life (6 items) and personal health and well-being (10 items). The original questionnaire was already developed in English and Bahasa 
Malaysia to break the time-consuming and tedious questionnaire. It makes the way for respondent easier, faster and more pleasant to answer the survey given (Dolnicar et al., 2011).

This study preferred to use the 10-point Likert scale type for the reliability of the data compared to 5-point or 7-point Likert scale. There are several reasons for choosing this type scales. First, the larger spectrum of choices means it is offers the respondent to pick the 'exact' one (which he prefers most) rather than to pick some 'nearby' or 'close' option (Joshi et al., 2015) compared to adjacent of 5 point scale variation. Thus, it is likely produce a high reliable scale. Second, the wider distribution of scores gives more discriminating power when it's around the mean (Nor Asiah et al., 2011). Hence, the descriptive statistics, independent t-test and two-way ANOVA will be analysing based on four research objectives in this study to test the overall means scores from this scales. Allen and Rao (2000) stipulated the constitution of covariance is easier when two variables more disperse, hence means is greater. Moreover, Cummins and Gullone (2000) also recommends used a 10-point Likert scale for measuring subjective QOL. For example, the creation of dependency models requires a strong covariance. Thus, for the development of theoretical framework too, the 10-point Likert scale is recommended for this study.

\section{Instrument Reliability}

A pilot test was conducted to assess the reliability and also, using Cronbach's coefficient alpha for consistency on the 65 items under nine dimensions of QOL questions. Nine of the items were grouped under the remunerations and benefits, eight under job characteristics, seven under interpersonal relationships, six under work environment, seven under organisational support, and facilities, eight under organisational policies and management style, five under safety \& security assurance, six under individual and family life, and nine under personal health and well-being. Guy et al. (1987) stipulated the number of items more than five for each construct must be measured to prove these strong coefficient alphas. Moreover, Nunnally \& Bernstein (1994) stated an instrument is said to be reliable if it yields similar result when used repeatedly, regardless of variations and can be applied for various related circumstances. Table 2 shows the reliability coefficients for the pre-test reliability analysis and the alpha coefficients values obtained from .840 to .965. Thus, it is meeting the Nunnally and Bernstein's (1994) requirement of .7 as the acceptable reliability level and good internal consistency among the items. Meanwhile, the overall alpha value was .978 (pre-test). This pre-test also support the Kline (1995) recommendation that alpha value should be never drop below 7 for the minimum of a good test. Subsequently, based on this pre-test results discernible that all alpha values are relatively high, satisfactory and impressively.

Table 2. Cronbach's Alpha Reliability Pre-Test Results

\begin{tabular}{clcc}
\hline No. & Constructs of QOL & Number of items & Cronbach's Alpha \\
\hline 1. & Remunerations and benefits (c1c9) & 9 & .919 \\
2. & Job characteristics (c10c17) & 8 & .926 \\
3. & Interpersonal relationships (c18c24) & 7 & .941 \\
4. & Work environment (c25c30) & 6 & .929 \\
5. & Organizational support and facilities (c31c37) & 7 & .840 \\
6. & Organizational policies and management style (c38c45) & 8 & .946 \\
7. & Safety and security assurance (c46c50) & 5 & .930 \\
8. & Individual and family life (c51c56) & 6 & .965 \\
9. & Personal health and well-being (c5765) & 9 & .902 \\
\hline & Overall QOL (c1c65) & 65 & .978 \\
\hline
\end{tabular}


INTERNATIONAL JOURNAL OF ACADEMIC RESEARCH IN BUSINESS AND SOCIAL SCIENCES

Vol. 8, No. 6, June 2018, E-ISSN: 2222-6990 @ 2018 HRMARS

\section{Conclusion}

In this article, we study and overview about the history of armoured vehicle procurement in Malaysian Army, defence offset procurement, giving an early exposure on statistics that will be using to measure the four objectives of the study, proposing a new theoretical framework for societal welfare, measuring its impacts through an adopted and adapted QOL instrument and analyses for reliability data. Based on this study, it may give an exposure to the public, private sector or defencerelated industry how importance of social welfare that able to impact the employees' QOL in DRBHicom Defence Technologies Sdn. Bhd. (DEFTECH), Pekan Plant, Pahang and Defence Services Sdn. Bhd. (DSSB), Nilai, Negeri Sembilan as the respondents of this study. All 65 items under nine dimensions of QOL were tested using the 10-Likert scale type for reliability and Cronbach's coefficient alpha for consistency of the data. The data were collected at a single point in time in both research locations. Subsequently, this research will be continuing investigating in defence offset procurement via armoured vehicle production and meeting the requirements of Malaysia's Defence Offset Procurement Policy.

\section{Acknowledgement}

This work is part of a research project entitled "Transfer of Technology and Socio-Economic Impact of Malaysian Military Armoured Vehicle Procurement", funded by Long Research Grant Scheme, Project Code No. LRGS/B-U/2013/UPNM/DEFENCE\&SECURITY-P5 led by Professor Dr. Jegak Uli supported by Ministry of Higher Education. My gratitude also goes to National Defence University of Malaysia for their continuous support and the support is gratefully acknowledged.

\section{Corresponding Author}

Nurhanis Amalina binti Roslan, National Defence University of Malaysia, Kem Sungai Besi, 57000 Kuala Lumpur, Malaysia, Email: nurhanisamalinaroslan@gmail.com

\section{References}

Samsudin, A. \& Ibrahim, S. A. (2014, December 6). DEFTECH Delivers Its First 12 Infantry Fighting Vehicles to be Malaysian Army. Retrieved from https://www.drb-hicom.com/wpcontent/uploads/2016/09/Press-Release-for-handing-over-of-AV8-2-Dec-latest-1600hrs.pdf

Antill, P. (2014). A New Era for Armoured Fighting Vehicles. Defence Procurement International, (Summer), 68-74.

Aparow, V. R., Hudha, K., Hamdan, M. M., \& Abdullah, S. (2015). Study on dynamic performance of armoured vehicle in lateral direction due to firing impact. Advances in Military Technology, 10(2), 5-20.

Arkib (2000, November 9). Kilang Deftech ditempatkan di Pekan. Utusan Online. Retrieved from http://ww1.utusan.com.my/utusan/info.asp?y=2000\&dt=1110\&pub=utusan malaysia\&sec=E konomi\&pg=bs 05.htm

Asean Defence Journal. (2014, March). Top Brass Interview with General Datuk Raja Mohamed Affandi Noor, Chief of Army, Malaysia. Asean Defence Journal, (pp. 22-24). Retrieved from http://www.adj.com.my/viewer/?b=adj\&i=F5B397DB-FDD2-6C7D-74BBAF85BFAD7CFD\&a=1\#p=25

Bradford, J. C. (2006). International Encyclopedia of Military History. Volume I. Great Britain: Routledge 
INTERNATIONAL JOURNAL OF ACADEMIC RESEARCH IN BUSINESS AND SOCIAL SCIENCES

Vol. 8, No. 6, June 2018, E-ISSN: 2222-6990 @ 2018 HRMARS

Cummins, R. A. \& Gullone, E. (2000). Why we should not use 5-point Likert scales: The case for subjective quality of life measurement. In Second International Conference on Quality of Life in Cities (pp. 74-93). Singapore: National University of Singapore.

Dolnicar, S., Grün, B \& Leisch, F. Quick, simple and reliable: forced binary survey questions, International Journal of Market Research, 53(2), 2011, 231-252.

Green, G. H., \& Irving, J. N. B. (1976). British Policy for Defence Procurement. The RUSI Journal, 121(3), 20-28. http://doi.org/10.1080/03071847609421250

Guillou, S., Lazaric, N., Longhi, C., \& Rochhia, S. (2009). The French defence industry in the knowledge management era: A historical overview and evidence from empirical data. Research Policy, 38, 170-180. http://doi.org/10.1016/i.respol.2008.10.015

Guy, R. F., Edgley, C. E., Arafat, I. and Allen, D. 1987. Social Research Methods: Puzzles and Solutions, Boston, MA: Allyn \& Bacon.

Hambleton, P., Keeling, S. \& McKenzie, M. (2008). QUALITY OF LIFE IS ... : THE VIEWS OF OLDER RECIPIENTS OF LOW-LEVEL HOME SUPPORT. Social Policy Journal of New Zealand, (33), 146162.

Heuninckx, B. (2008). A Primer to Collaborative Defence Procurement in Europe: Troubles, Achievements and Prospects. Public Procurment Law Review, 17(3), 29-30.

Heuninckx, B. (2015). Defence Procurement and the European Defence Equipment Market: the Virtues of Kissing the Frog. Procurement Law Journal, (4), 319-337.

Irman Moad. (2010). Malaysian Army Optimistic for the Future. Asian Defence Journal, April(2), 1618.

Jonathan Aitken MP (1994) Defence procurement: Past, present and future, The RUSI Journal, 139:1, 39-42, http://dx.doi.org/10.1080/03071849408445784

Kaplan, R. M., \& Ries, A. L. (2007). Quality of life: Concept and definition. COPD: Journal of Chronic Obstructive Pulmonary Disease, 4(3), 263-271. http://doi.org/10.1080/15412550701480356

Kirchwehm, H. (2014a). Impact of Defence Offsets On The Companies of The Participating Industry A Case Study Based Examination. International Journal of Business Research and Management (IJBRM), 5(4), 52-63.

Kirchwehm, H. (2014b). Success Factors in Offset Deals: A Case Study Based Examination. International Journal of Business Research and Management (IJBRM), 5(2), 28-40.

Kogi Balakrishnan, \& Matthews, R. (2009). THE ROLE OF OFFSETS IN MALAYSIAN DEFENCE INDUSTRIALISATION. Defence and Peace Economics, 20(4), 341-358. http://doi.org/10.1080/10242690802333117

Kogila Balakrisnan. (2007). Evaluating the Effectiveness of Offsets as a Mechanism for Promoting Malaysian Defence Industrial and Technological Development. Cranfield University. Retrieved from https://dspace.lib.cranfield.ac.uk/bitstream/1826/2504/1/final thesis07ver7.pdf

Kogila Balakrishnan. (2008). Defence Industrialisation in Malaysia: Development Challenges and the Revolution in Military Affairs. Security Challenges, 4(4), 135-155.

Kwong, F. W. (2014). History of Vehicles of the Armoured Corps: Past and the Present. Malaysia: The Royal Malaysian Armoured Corps.

Kwong, F.W., Ananthan, S., Jegak Uli, Kogila Balakrishnan \& Pickl, S. (2016). Transfer of Technology in the Procurement of Armoured Vehicles: An Empirical Approach. In 8th International Conference on Humanities and Social Sciences (ICHiSS) (pp. 602-614). Malaysia: UPNM Press.

Markowski, S., \& Hall, P. (1998). Challenges of defence procurement. Defence and Peace Economics, 9(1-2), 3-37. http://doi.org/10.1080/10430719808404892 
INTERNATIONAL JOURNAL OF ACADEMIC RESEARCH IN BUSINESS AND SOCIAL SCIENCES

Vol. 8, No. 6, June 2018, E-ISSN: 2222-6990 @ 2018 HRMARS

Massam, B. H. (2002). Quality of life: Public planning and private living. Progress in Planning, 58(3), 141-227. http://doi.org/10.1016/S0305-9006(02)00023-5

McGuffog, T. (2011). Improving value and certainty in defence procurement. Public Money \& Management, 31(6), 427-432. http://doi.org/10.1080/09540962.2011.618767

Eliyas, M. \& Vithal, H. K. (2014). CONCEPT DESIGN OF SPECIAL VEHICLE FOR INDIAN MILITARY. SASTECH Journal, 13(1), 39-45

Ministry of Defence. (2004). DEFENCE INDUSTRY BLUEPRINT. MALAYSIA: Defence Industry Division, Ministry of Defence. Retrieved from www.primenet.com.my

Ministry of Finance. (2011). POLICY AND GUIDELINE ON OFFSET PROGRAMMES IN GOVERNMENT PROCUREMENT. MALAYSIA

Keling, M. F., Mohamad, M. H. \& Batau, M. F. A. (2016). Faktor dan Proses Pembangunan Dasar Pertahanan Negara Malaysia. Malaysian Journal of Social Sciences and Humanities (MJ - SSH), 1(3), 31-41

Neuman, S. G. (2010). Power, Influence, and Hierarchy: Defense Industries in a Unipolar World. Defence and Peace Economics, 21(1), February, pp. 105-134

Nunnally, J. C. \& Bernstein, I. 1994. Psychometric Theory. New York: McGraw Hill.

Otieno, G. O. \& Noor, I. S. (2014). Factors affecting logistic support in military operations: Case of the Kenya Defence Forces. International Academic Journal of Procurement and Supply Chain Management, 1 (3), 1-11

Ruževičius, J. (2014). Quality of Life and of Working Life: Conceptions and Research. In 17th ToulonVerona International Conference. Liverpool (England).

Rozali, A., Rampal, K. G., Shamsul Bahri, M. T., Sherina, M. S., Shamsul Azhar, S., Khairuddin, H., \& Sulaiman, A. (2009). Low Back Pain and Association with Whole Body Vibration Among Military Armoured Vehicle Drivers in Malaysia. Med J Malaysia, 64(3), 197-204.

Skorupka, Z., Kajka, R., \& Kowalski, W. (2011). ARMOURED VEHICLES BRAKES TESTS. Journal of KONES Powertrain and Transport, 18(3), 449-455.

Tippe, S. (2013). Defense Offset Policy in Indonesia. International Journal of Administrative Science \& Organization, 20(2), 85-89.

Sylvester, O. A., \& Tosin, A. O. (2016). Influence of Demographic Variable on Quality of Life among Women in Ibadan Metropolis, Oyo State of Nigeria. International Journal of Applied Psychology, 6(3), 56-63. http://doi.org/10.5923/j.ijap.20160603.02

Theofilou, P. (2013). Quality of life: Definition and measurement. Europe's Journal of Psychology, 9(1), 150-162. http://doi.org/10.5964/ejop.v9i1.337

Tokuda, Y., Jimba, M., Yanai, H., Fujii, S., \& Inoguchi, T. (2008). Interpersonal trust and quality-of-life: a cross-sectional study in Japan. PloS One, 3(12), e3985. http://doi.org/10.1371/journal.pone.0003985

Ungaro, A. R. (2013). TRENDS IN THE DEFENCE OFFSETS MARKET. In 17th Annual International Conference on Economics and Security (ICES) (pp. 1-12). Rome. Retrieved from http://ssrn.com/abstract $=2386528$

Ventegodt, S., Hilden, J., \& Merrick, J. (2003). Measurement of quality of life I. A Methodological Framework. TheScientificWorldJournal, 3, 950-61. http://doi.org/10.1100/tsw.2003.75

Kapoor, Y. (1990). Philosophy of Modernisation: Indian Mechanised Forces. CLAWS Journal, 94-103.

Safari, Z. (2014, June 9-10). Malaysian Offset Program: A Tool for National technology and Economic Development. 